Korte, Barbara / Sylvia Paletschek,

Blick zurück nach vorn: (Frauen-)Geschichte in feministischen Zeitschriften des 19. Jahrhunderts in Großbritannien und Deutschland, in: Cheauré, Elisabeth / Sylvia Paletschek / Nina Reusch (Hg.), Geschlecht und Geschichte in populären Medien, Bielefeld 2013, S. 105-136. 


\title{
Blick zurück nach vorn: (Frauen-)Geschichte in feministischen Zeitschriften des 19. Jahrhunderts in Großbritannien und Deutschland
}

\author{
Barbara Korte Und Sylvia PALETSCHEK
}

\section{FrauenemanzipationsbeWEGUNGEN UND GESCHICHTE}

Für die seit der Mitte des 19. Jahrhunderts in Europa entstehenden, in den Jahrzehnten um 1900 zu öffentlichkeitswirksamen Massenbewegungen herangewachsenen europäischen Frauenbewegungen war die Beschäftigung mit $\mathrm{Ge}$ schichte ein wichtiges Moment der Identitätsstiftung und der Legitimation ihrer Forderungen (Grever 1997; Paletschek/Pietrow-Ennker 2004: 301-307). Aktivistinnen der >alten< Frauenbewegung waren meist die ersten, die im frühen 20. Jahrhundert eine Geschichte ihrer Bewegung schrieben oder die Initiative ergriffen, Quellen zu sammeln. ${ }^{1}$ Frauenrechtlerinnen der ersten Stunden beschäftigten sich aber nicht nur mit der >eigenen< Geschichte ihrer politischen Bewegung, sondern verfassten allgemeine Werke zur Frauengeschichte oder zu herausragenden Frauen. Es gab also bereits eine Frauengeschichte vor der in den 1970er Jahren aufkommenden akademischen Frauen- und Geschlechtergeschichte, die wiederum ihren Anstoß aus der zeitgenössischen Frauenbewegung und den neuen sozialen Bewegungen erhielt. Dass die Beschäftigung mit Frauengeschichte im 19. und 20. Jahrhundert insgesamt - wenn auch nicht ausschließlich - eng mit der Entstehung feministischer Bewegungen verknüpft war, hat mit der Abbildung der politischen und gesellschaftlichen Geschlechterverhältnisse auch auf die jeweilige Wissenskultur und insbesondere den Wissenschaftsbetrieb zu tun.

1 Vgl. hierzu auch die Ausführungen in der Einleitung dieses Bandes. 
4

Mit der sich seit dem Ende des 18. und vor allem im 19. Jahrhundert vollziehenden Professionalisierung und Verwissenschaftlichung der Geschichtsschreibung verstärkte sich der Ausschluss von Frauen - sowohl als Subjekten wie Objekten der Geschichtsschreibung (Smith 1984; Smith 1998: 103-156). Dennoch gab es bereits in den Jahrzehnten um 1800 auf dem Buchmarkt erfolgreiche Historikerinnen wie z.B. Catherine Macaulay, die Strickland-Schwestern, Therese Huber oder Johanna Schopenhauer, die jedoch in der Folgezeit von der auf die akademische Geschichtsschreibung konzentrierten Historiographiegeschichte vergessen wurden (Smith 1998: 37-69; Epple 2003; Epple 2004: 21-33). Mit der Verwissenschaftlichung und Professionalisierung der Geschichtsschreibung im 19. Jahrhundert weitete sich die Kluft zwischen populärer und akademischer Geschichtsschreibung. Es vollzog sich trotz weiter bestehender Interaktionen eine schärfere Trennung zwischen populärer und akademischer Geschichtsschreibung, die von einer geschlechtsspezifischen Arbeitsteilung und Themenwahl überlagert wurde (Smith 1998; Epple/Schaser 2009: 7-26).

Mittlerweile liegen zu der von Frauen im 19. Jahrhundert verfassten, faktualen wie fiktionalen Geschichtsschreibung mehrere Arbeiten vor. ${ }^{2}$ In den Forschungen zu feministischen Bewegungen sowie zum Verhältnis von Geschlecht und Erinnerungskultur finden sich Hinweise zur Funktion von Geschichte als Legitimationsmittel für Emanzipationsbewegungen (Grever 1997; Paletschek/Schraut 2008: 7-28). Die Geschichtsbilder und die Geschichtspolitik der Frauenbewegungen sind jedoch bisher nicht systematisch untersucht worden.

Wir möchten hierzu einen Beitrag leisten und im Folgenden anhand zweier Fallstudien skizzieren, wie sich feministische Zeitschriften in Deutschland und Großbritannien im Zeitraum zwischen den 1850er und den 1890er Jahren mit (Frauen-)Geschichte auseinandersetzten und selbst zur (Frauen-)Geschichtsschreibung beitrugen. Dabei soll der deutsch-britische Vergleich dazu dienen, über die Konturierung von Gemeinsamkeiten und Unterschieden die Spezifik und Funktion der in den Frauenbewegungen kursierenden Geschichtsbilder herauszuarbeiten. Periodika waren zentrale Artikulations- und Verbreitungsmedien der Frauenbewegungen des 19. Jahrhunderts. ${ }^{3}$ Sie erreichten weibliche wie (in der Minderzahl vertretene) männliche Mitglieder und Sympathisanten der Bewegung und wurden partiell von einer breiteren Öffentlichkeit wahrgenommen.

2 Siehe neben den bereits genannten Arbeiten von Smith und Epple u.a. Spongberg 2004, Spongberg/Caine/Curthoys 2007, Paletschek 2007, Epple/Schaser 2009.

3 Zur Presse der deutschen Frauenbewegung siehe knapp zusammenfassend Wischermann 2003: 6-13; zu den ersten deutschen Frauenzeitschriften und ihrem Publikum im späten 18. Jahrhundert siehe Weckel 1998. 
Die feministischen Zeitschriften stellten ein wichtiges Forum zur organisatorischen Konsolidierung, zur ideologischen Positionsbestimmung und zur öffentlichen Repräsentation der Frauenbewegungen dar.

Folgende Fragestellungen leiten unsere Untersuchung: Welche historischen Traditionslinien und Geschichtsbilder konstruierten die Feministinnen des 19. Jahrhunderts in ihren Zeitschriften? Wie nutzten sie Geschichte als Legitimationsressource und Vehikel der Identitätsstiftung? Nahm Frauengeschichte hier einen besonderen Platz ein und welche Frauen oder weiblichen Lebensbereiche fanden Beachtung? War in den Zeitschriften der metahistorische Diskurs der Ausgrenzung von Frauen und weiblichen Handlungsräumen aus der akademischen (und dem Großteil der populären Geschichtsschreibung) ein Thema und wurde ggf. eine >Gegengeschichte< entworfen? Waren die feministischen Zeitschriften im Vergleich mit anderen Frauenzeitschriften >radikaler in ihrer Darstellung und Funktionalisierung von Geschichte? Welche nationalen Unterschiede bzw. transnationalen Gemeinsamkeiten lassen sich beobachten?

Wir konzentrieren uns auf feministische Zeitschriften, ${ }^{4}$ die organisatorisch eng mit den bürgerlichen Frauenbewegungen der ersten Organisationsphase ${ }^{5}$ im Zeitraum zwischen ca. 1860 und 1900 verbunden waren. Für Großbritannien sind dies das English Woman's Journal (1858-1864) und flankierend seine Folgepublikationen Victoria Magazine (1863-1880) und Englishwoman's Review of Social and Industrial Questions (1866-1910); alle drei Publikationen sind eng

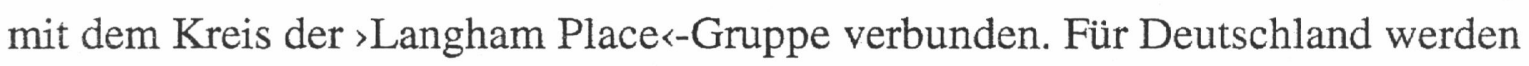
im Untersuchungszeitraum die Neuen Bahnen (1866-1919) ausgewertet, das Or-

4 Der Begriff Feminismus wurde erst seit den 1890er Jahren und mit Beginn des 20. Jahrhunderts in einigen europäischen Frauenemanzipationsbewegungen als Selbstbezeichnung verwendet, so vor allem im anglo-amerikanischen Raum, im romanischen Sprachraum und z.T. in Südeuropa, nicht jedoch in Nord-, Mittel- und Osteuropa. So war im deutschen Sprachraum die Bezeichnung als Frauenrechtlerin oder Emanzipierte geläufig. Zum Problem der Bezeichnungen siehe Offen 2000: 19-21, Paletschek/ Pietrow-Ennker 2004a: 5-8. Wir verstehen unter feministischen Zeitschriften solche, die in Verbindung mit den Frauenemanzipationsbewegungen standen oder von deren Aktivistinnen herausgegeben wurden und das Ziel verfolgten, die gesellschaftliche, rechtliche, wirtschaftliche und politische Situation von Frauen zu verbessern, deren Handlungsspielraum zu erweitern und die männliche Hegemonie kritisch zu hinterfragen. Wir folgen damit der Definition von Karen Offen sowie Doughan/Sanchez 1987: vii.

5 Als Versuch einer (flexiblen) Phasenbildung der europäischen Frauenbewegungen vgl. Paletschek/Pietrow-Ennker 2004b: 307-315. 
1

gan des 1865 gegründeten Allgemeinen Deutschen Frauenvereins (ADF), das von Louise Otto und Auguste Schmidt herausgegeben wurde. ${ }^{6}$

\section{DAS BRITISCHE BEISPIEL}

\section{Die britische Frauenbewegung und ihre Zeitschriften}

Die >Langham Place<-Gruppe, so benannt nach ihrem Londoner Zentrum in den 1850er Jahren, wurde von Frauen gegründet und maßgeblich getragen, die sich der Bourgeoisie zurechneten (Rendall 2007). Ihnen war bewusst, dass sie, um Gehör zu finden, ihre politischen Anliegen mit Rücksicht auf dominante Geschlechtsrollenvorstellungen vorbringen mussten - Vorstellungen, die sie z.T. auch persönlich teilten. ${ }^{7} \mathrm{Zu}$ den besonderen Anliegen der >Langham Place<Gruppe zählten die Verbesserung der weiblichen Bildung und Rechtsstellung, insbesondere verheirateter Frauen, sowie eine Erweiterung der Arbeitsmöglichkeiten für Frauen auch der bürgerlichen Schichten. Das Organ der Gruppe, das English Woman's Journal, hatte nur eine bescheidene Zirkulation von 500-1000 Exemplaren (Beetham 2003: 175), wurde jedoch weit über die subskribierten Exemplare hinaus verbreitet und wahrgenommen. Es war, wie Fraser, Green und Johnston (2003) feststellen, »an important extension of the work of the women of Langham Place « und begründete »new generations of social and political magazines for women« (149). Auch wenn das EWJ aufgrund von Finanzierungsproblemen nach 78 monatlichen Nummern 1864 eingestellt wurde, darf seine Bedeutung nicht unterschätzt werden. Es präsentierte sich seinen Leserinnen und Lesern als seriöse und intellektuell engagierte Zeitschrift und diskutierte die soziale Lage von Frauen in Großbritannien in Bezug zu anderen Reformanliegen, ohne eine Inversion von Geschlechterrollen zu fordern (ebd.: 155).

6 Hinweis zur Zitierweise: Im Folgenden geben wir Artikel, soweit dies ermittelt werden konnte, mit Band- oder Jahrgangsnummer/Heftzahlen bzw. Datum sowie, wo zum Auffinden erforderlich, mit Seitenzahlen an. Dabei beziehen sich die Bandzahlen der britischen Zeitschriften meist auf Halbjahre. Viele britische Frauenzeitschriften sind mittlerweile digitalisiert, so dass sich Artikel über Suchfunktionen ermitteln lassen. Die Neuen Bahnen sind über die Gerritsen Collection digitalisiert zugänglich.

7. Zum Oszillieren der britischen bürgerlichen Frauenbewegung und ihrer Publikationen zwischen emanzipatorischen Forderungen und traditionellen Weiblichkeitsidealen siehe auch Fraser/Green/Johnston 2003: 153-154. 
Hinter dem EWJ stand ein Team der >Langham Place<-Frauen; seine Hauptherausgeberin war Bessie Rayner Parkes (1829-1925). ${ }^{8}$ Viele Frauen, die mit dem $E W J$ assoziiert waren, arbeiteten auch an seinen Folgepublikationen mit. Von diesen war das von Emily Faithfull herausgegebene Victoria Magazine $(V M)$ kommerzieller orientiert, um ein breiteres Publikum erreichen und auf dem Markt bestehen zu können. Die ab 1863 erscheinende Englishwoman's Review of Social and Industrial Questions (ER) druckte weitaus weniger historische und biographische Artikel ab als $E W J$ und $V M$, denn sie verstand sich primär als »a current awareness bulletin, with few long articles, theoretical or otherwise, but very many short notices of feminist activities and relevant events « (Doughan/ Sanchez 1987: 3). Die $E R$ ist, wie sich zeigen wird, jedoch eine wichtige Quelle für die beginnende Selbsthistorisierung der englischen Frauenbewegung.

\section{Eine Vergleichsfolie: Geschichte in nicht-feministischen Frauenzeitschriften}

Zur Bestimmung des historischen >Profils < dieser feministischen Zeitschriften ist ein kurzer Blick auf das >Durchschnittsprofil< zeitgleicher nicht-feministischer Frauenzeitschriften hilfreich. Diese Zeitschriften (wie z.B. die Queen, das Englishwoman's Domestic Magazine oder das Ladies' Treasury) ${ }^{9}$ hatten verschiedene Träger-, Herausgeber- sowie Leserschaften und waren ideologisch unterschiedlich imprägniert. Trotzdem zeigen sich Überschneidungen bei Präferenzen für bestimmte historische Themenbereiche. Auffällig ist dabei ein - im Vergleich zu zeitgleich erscheinenden Familienzeitschriften - hoher Anteil an weiblich konnotierten Geschichtsthemen, während die vorherrschend mit männlichen Handlungsräumen verbundenen Geschichtsbereiche wie Politik und Militär weitgehend ausgeblendet wurden. Spezielles Interesse galt der Geschichte weiblichen Lebens in verschiedenen Epochen, der Kulturgeschichte des Haushalts, ${ }^{10}$

$8 \mathrm{Zu}$ Geschichte und Hintergründen des EWJ siehe Nestor 1982, Herstein 1985, Rendall 1987, Dredge 2005, Mussell 2005-7 und Schroeder 2012.

9 Alle drei waren auflagenstarke Zeitschriften, die Leserinnen der oberen und mittleren Schichten erreichten und lange Laufzeiten hatten: The Queen 1861-1967, The Englishwoman's Domestic Magazine 1852-79 und The Ladies' Treasury 1858-1895. Zu ihrer genaueren Charakterisierung siehe die entsprechenden Einträge im Dictionary of Nineteenth-Century Journalism.

10 Zum Beispiel in der siebenteiligen Artikelserie »Lares et Penates « des monatlich erscheinenden Englishwoman's Domestic Magazine (EDM), von Bd. 4 (2. Serie)/39, März 1868 bis Bd. 5/47, November 1868. 
der Mode und Kosmetik ${ }^{11}$ sowie der Handarbeit. ${ }^{12}$ Dazu kam ein hoher Anteil an Biographien historischer Frauen seit der Antike. Häufig waren dies Herrscherinnen, ${ }^{13}$ das Interesse galt vereinzelt aber auch Kämpferinnen wie Jeanne d'Arc ${ }^{14}$ und Revolutionärinnen wie Charlotte Corday. ${ }^{15}$ Vielfach porträtiert wurden zudem Wohltäterinnen, ${ }^{16}$ Literatinnen wie Madame de Staël ${ }^{17}$ oder Künstlerinnen wie Angelica Kauffmann, welche dem Ladies' Treasury als Beweis dafür galt, »that genius had no sex« (1860: 111-112). Das Spektrum der Frauenbiographien war bemerkenswert international, europäisch orientiert und verweist auf ein zumindest implizites Programm, die Beteiligung von Frauen an der Geschichte sichtbar bzw. wieder sichtbar machen zu wollen. ${ }^{18}$ Nicht zuletzt die Serialität von Frauenporträts in fast allen Zeitschriften war geeignet, eine Kontinuität solcher weiblicher Bedeutsamkeit aufzuzeigen, ${ }^{19}$ wie die Queen zu Beginn ihrer

11 Zum Beispiel in der Artikelserie »Costumes and Fashions in Olden Times« der wöchentlich erscheinenden Queen, vom 26. Januar bis 11. Mai 1867. Für eine umfangreiche Kosmetikgeschichte konnte das EDM sogar den marktführenden Parfümhersteller in Großbritannien gewinnen: Eugene Rimmels »A History of Perfumery and the Toilet« erschien in zwölf Teilen 1864 (2. Serie, Bde. 8 und 9).

12 Zum Beispiel »Royal and Noble Lady Workers«, Queen, 15. März 1879; »Woman's Work in the Middle Ages«, The Ladies' Treasury, Februar bis Juni 1868.

13 Das EDM veröffentlichte 1862 und 1863 »Historical Female Biographies« von Agnes Strickland, die in verdeckter Ko-Autorenschaft mit ihrer Schwester Elizabeth die Mode der royal female biography initiiert hatte und eine der populärsten Autorinnen auf dem Gebiet war.

14 »Fearless and Spotless«, EDM, Bd. 11 (2. Serie)/20, August 1866.

15 Das EDM porträtierte Charlotte Corday sogar zweimal: in Bd 4/6, Oktober 1855, und in Band 2 (3. Serie)/13, Januar 1866. Zu Charlotte Corday siehe auch den Beitrag von Sylvia Schraut in diesem Band.

16 Zu Elizabeth Fry, einer Pionierin der Gefängnis- und Hospitalreform, siehe »Elizabeth Fry«, EDM, Bd. 4/9, September 1856 und Queen, August 1867.

17 Dabei war die Einschätzung de Staëls durchaus unterschiedlich. Man würdigte sie als Gegnerin Napoleons und führende Intellektuelle ihrer Zeit, aber die Autorin von »Madame de Stael«, EDM, November 1853, missbilligte de Staëls angebliche Vernachlässigung ihrer Ehe, während das Ladies' Treasury sie im März 1857 auch als vorbildliche Ehefrau darstellte und so jeden Anlass zur Kritik ausräumte.

18 Programmatisch ist in dieser Hinsicht der Titel einer Serie in der Queen: »Women Who Have Appeared upon the Surface«, 18. April bis 20. Juni 1863.

19 Zur Bedeutung der Biographie als einer bevorzugten Form der weiblichen Historiographie siehe Smith 2001: 715. 
mehrteiligen Serie »Gallery of Celebrated Women« ausdrücklich hervorhob: »It is our intention to give in these pages portraits of celebrated women who have existed in all ages, and in all civilised countries « (17. August 1867: 129, unsere Hervorhebung). In diesem Sinne hatten auch die britischen nicht-feministischen Frauenzeitschriften - trotz ihrer oft prononcierten Distanzierung von der Frauenbewegung ${ }^{20}$ - ein zumindest protofeministisches frauenhistorisches Bewusstsein. ${ }^{21}$ Ausgeprägter und expliziter lässt sich ein solches in den Zeitschriften der Frauenbewegung nachweisen.

\section{Feministisches Einschreiben von Frauen und ihren Leistungen in die Geschichte}

Das English Woman's Journal weist gegenüber dem Durchschnittsprofil nichtfeministischer Frauenzeitschriften einige charakteristische Abweichungen auf. Ein besonderes Anliegen des $E W J$ war es, Berufsfelder für Frauen vorzustellen. Diese wurden nicht nur für die Gegenwart beschrieben, sondern auch in historischen Dimensionen beleuchtet, da so demonstriert werden konnte, dass Frauen Arbeiten wie das Anfertigen von Holzschnitten für den Buchdruck, die Krankenpflege oder das Telegraphieren ${ }^{22}$ bereits in der Vergangenheit körperlich und moralisch unbeschadet bewältigt hatten. Da das EWJ - wie auch das Victoria Magazine - keine Artikel zu Themen wie Mode und Haushalt abdruckte, gibt es hierzu auch keine historischen Artikel. Auch Biographien von Männern sind im

20 So schrieb die Queen programmatisch in ihrer ersten Nummer: »When we write for Women, we write for Home. We shall offend very few when we say that women have neither heart nor head for abstract political speculation; while as for our own liberties, or our political principles, they may be safely left to men bred in the honest independence of English households.« (»Review of the Week«, 7. September 1861: 1)

21 So unterstützte die Queen am 18. Mai 1872 das Anliegen von Frauen, die zum Medizinstudium in Edinburgh zugelassen werden wollten, mit einem Artikel über einen antiken Präzendenzfall: »The Lady Doctors of Ancient Athens: A Story for Modern Athens «. Das Ladies' Treasury wies in seiner Bücher- und Zeitschriftenschau »Literary Notices« (Juli 1876: 434) auf Artikel im feministischen Victoria Magazine hin, u.a. eine Biographie Caroline Herschels, zu der unten mehr gesagt wird.

22 »The History of Wood-Engraving«, EWJ, Bd. 1/3, Mai 1858; »The Rise and Progress of Telegraphs«, EWJ, Bd. 4/21, November 1859 und 22, Dezember 1859; »Nursing, Past and Present«, EWJ, Bd. 10/60, Februar 1863. 
$E W J$ - fast programmatisch - rar, $^{23}$ während das marktorientierte $V M$ wie andere Zeitschriften für Frauen häufiger Biographien von männlichen Künstlern und Schauspielern früherer Epochen abdruckte.

Legten auch die nicht-feministischen Frauenzeitschriften Wert darauf, die intellektuelle Ebenbürtigkeit von Frauen herauszustellen - und diese im Kontext des allgemeinen gesellschaftlichen Fortschritts ab Mitte des 19. Jahrhunderts als bereits weitgehend realisiert zu präsentieren - setzte das $E W J$ hier noch deutlichere Akzente. So betonte ein Artikel »On the Social Position of Women in the XIXth Century « (Bd. 1/4, Juni 1858), dass Frauen sich nicht nur als Künstlerinnen hervorgetan, sondern auch - und zwar als professionelle Autorinnen - um die Verbreitung von Wissen verdient gemacht hatten, nicht nur im Bereich der Geschichte und der Künste, sondern auch in der Mathematik und den Naturwissenschaften:

»The manners and customs of long perished ages have been rescued from the formal custody of archaeology, and restored to that of vivid history by the labours of Miss Aikin, Miss Costello, Miss Agnes Strickland, and of our learned and accomplished neighbour, Miss Frere. Mrs. Jamieson is the best living expositor of the treasures of Mediaeval art, and the best delineator of the minuter lights and shadows of female character, whether real or ideal. We have seen astronomy represented by Miss Herschel, chemistry by Mrs. Marcet, and botany by Mrs. Loudon. The list might be increased indefinitely, but I will not weary your attention with a further enumeration of names.« (280)

Mit einem Doppelartikel über »Caroline Frances Cornwallis« (Bd. 13/76, Juni 1864 und 77, Juli 1864) würdigte das $E W J$ eine der produktivsten Popularisiererinnen von Wissenschaft des früheren 19. Jahrhunderts. ${ }^{24}$ Cornwallis wird dabei als Frau präsentiert, die Freude an der Gelehrsamkeit hatte und für sich ein >natürliches Recht in Anspruch nahm, die intellektuellen Fähigkeiten zu nutzen, mit denen sie ihr Schöpfer ausgestattet hatte:

»She acquired deep learning, not to gratify ambition, or that it might be a means to gain any worldly end, but because she loved it for its own sake, because she felt the capability with which the Creator had endowed her, and desired to improve to the utmost the talents

23 Die wenigen porträtierten Männer scheinen dabei auf Reformer beschränkt gewesen zu sein wie »George Combe« (Nachruf), EWJ, Bd. 2/7, September 1858, und »Heinrich Pestalozzi«, EWJ, Bd. 10/55, September 1862 und 56, Oktober 1862.

24 Zur Popularisierung von Naturwissenschaften im 19. Jahrhundert in Großbritannien siehe auch Schwarz 2008: 74-91. 
with which $\mathrm{He}$ had entrusted her; and she gave forth what she had acquired because she believed that all who have gained truth ought to impart it, and that exertion of their abilities is doubly incumbent on those whose powers, by a strange contradiction, are usually fettered because it is doubted whether they exist.«(Juli 1864: 307)

Der Artikel macht seinen Leserinnen aber auch bewusst, dass Cornwallis ihr Geschlecht nicht öffentlich enthüllt sehen wollte, um ernst genommen zu werden. ${ }^{25}$ Vorurteile führten dazu, dass sie trotz ihrer anerkannten Verdienste zu einer der >versteckten< Frauen der Geschichte wurde.

Das Victoria Magazine setzte das Augenmerk auf naturwissenschaftlich profilierte Frauen fort, u.a. mit der Biographie Caroline Herschels. Ein langer Artikel betont, dass diese Frau keineswegs nur die Assistentin und Haushälterin ihres berühmten Bruders William war, sondern eine Wissenschaftlerin eigenen Rangs, auch wenn sie selbst zu bescheiden war, um sich dieses Rangs bewusst zu sein. Bereits der Titel, »Caroline Herschel: Astronomer«, signalisiert die Wertschätzung des Artikels deutlich, und der Text identifiziert sie als »the indefatigable and invaluable fellow-worker of the great astronomer «, deren Leistungen umso höher einzuschätzen sind, als sie in einer rückständigeren Zeit erbracht wurden: »in the last century the aspirations of Caroline Herschel would have been looked upon as revolutionary.« (Bd. 27/2, Juni 1876: 126) Allerdings soll auch der Eindruck vermieden werden, dass Caroline Herschels Leistungen als Astronomin, die sogar die Royal Astronomical Society öffentlich anerkannte, mit einem Verlust an Weiblichkeit einhergegangen wären. Herschel wird als Wissenschaftlerin und exemplarische (gebürtig deutsche) »Hausfrau« und fürsorgliche Schwester vorgestellt. $^{26}$

25 »The reason for this reticence was simply that she wished what was written to have its due weight, irrespective of the question as to who was the writer; and the state of society twenty-two years ago, when her works first begun to be published, was such that the only way to attain this was to conceal her name and sex.«(EWJ, Juni 1864: 232).

26 Auch nicht-feministische Frauenzeitschriften würdigen gelegentlich Leistungen von Frauen in den Naturwissenschaften, aber tendenziell geschieht dies, soweit die Materialgrundlage diese Schlussfolgerung zulässt, mit einer gewissen Zögerlichkeit und auch zeitlichen Verzögerung gegenüber den feministischen Zeitschriften. Das Ladies' Treasury wies zwar auf den Artikel des $V M$ über Caroline Herschel hin, begann einen eigenen Artikel über »Scientific Women« in Bd. 6/21, Juni 1881 aber mit einer gewissen Distanzierung von der Frauenbewegung: "We need not be fanatical admirers of women, or touch in any way the burning question of >Women's Rights<, when we maintain that there are women strong enough in mind and will to approach the most 
1

\section{Meta-historische Perspektiven und Umschreiben der Geschichte}

Die feministischen Frauenzeitschriften machten bewusst, welche Faktoren dazu führten, ob und wie Frauen kollektiv erinnert wurden: Im Fall von Cornwallis und Herschel seien Vorurteile und zu große persönliche Bescheidenheit dieser Erinnerung hinderlich gewesen, weil die Frauen selbst ihre Bedeutung herunterspielten. Aber auch die Geschichtsschreibung wird als Hindernis für eine angemessene Erinnerung und Würdigung weiblicher Leistungen identifiziert. Ein dezidiert reflektiertes meta-historiographisches Bewusstsein äußert sich etwa in einem Artikel des $E W J$ über »Domestic Life of German Ladies in the Sixteenth Century« (Bd. 5/26, April 1860). Ausdrücklich wird hier festgestellt, dass die Historiographie >männlich< konnotierte Bereiche der Geschichte wie Politik und Militär bevorzugt und > weiblich $<$ konnotierte Bereiche wie Sozial- und Alltagsgeschichte allenfalls als > Untergrund $<$ der scheinbar bedeutsameren Geschichte zur Kenntnis nimmt:

»The roll which the Muse of History bears in her hand is a Palimpsest. Those great events which shape the life of nations; the career of leaders and rulers; the death agony of old beliefs and worn-out empires; the birth throes of the new; these, with their kindred themes, make up its outward record, the record of the sword and the palm. The underwritten chronicle is for the most part fragmentary, its characters often dim and half-effaced; the man who would decipher it must make up his mind to bestow a good deal of patient labour on his task. Here you come upon a vivid picture, followed by a provoking gap; there the faintest possible sketch, a bare outline, which sends the puzzled student on a search for those hints and intimations whence it is to gain some form and colour. Yet the history, once spelled out and put together, shall seem to us not all unworthy of the pains it has cost. It presents sketches of household life; the customs and ways of thinking of the age; the private life and surroundings of those men who in any way stood before the world in their day and generation. « (102, unsere Hervorhebung)

difficult scientific problems, and to study them diligently and successfully« (327). Erst im Mai 1894 veröffentlichte das Treasury einen Artikel über »Caroline Herschel«, der jedoch ihre wissenschaftliche Leistung weitaus weniger betont als ihre hingebungsvolle Unterstützung des Bruders und programmatisch mit der Feststellung endet: »And the world of to-day is interested in her, not because she was a femme decorée, not because she discovered eight comets, but because she was a loyal, true, loving and devoted woman.«(Bd. 19/7: 286) 
1

Der Artikel fordert daher ein Um-Schreiben der Geschichte und eine neue Historiographie, an der Frauen beteiligt sind - nicht nur als Forschungsobjekte, sondern auch als forschende Subjekte:

$» B e$ it ours to lift in some degree the veil which time, and change, and circumstance, have all combined to weave over the real every-day life led by the ladies of that age and nation; those figures which appear as it were by chance in general history, and claim no more distinct memorials than a name in a genealogy, the monument they share with their husbands in some church, or a faded portrait on the walls of an ancient castle. Still, in mouldering letters and dusty archives traces of their personal existence may be found, and we present the truthful, though far too imperfect, sketch thus obtained to our readers, in the hope that some may share our own interest in this leaf we have borrowed from the records of the olive.«(102f.)

Ein Bestreben, die Rolle und Bedeutung von Frauen in der Geschichte (wieder) sichtbar zu machen, ist auch in den nicht-feministischen Frauenzeitschriften der viktorianischen Zeit zu erkennen. Das feministische EWJ artikuliert dieses Bestreben aber mit größerem Nachdruck und programmatisch, wobei sich auch hier die Umsetzung des Programms vor allem in biographischen Artikeln vollzieht. $\mathrm{Zu}$ den wenigen von einer bekannten Autorin signierten biographischen Artikeln im EWJ zählt ein zweiteiliger Beitrag über »Margaret of Norway« (Bd. 3/13, März 1859 und 14, April 1859) von Amelia Edwards; die neben literarischen und journalistischen auch historiographische Texte verfasste. ${ }^{27}$ Bereits der Beginn des Beitrags verkündet die Absicht, aus der Perspektive moderner feministischer Forderungen auf die Geschichte bedeutungsvoller Frauen zurück zu blicken: »At a time like the present, when women's claims form the subject of so much discussion, it is curious to turn back to the pages of old history and inquire what position was occupied and what influence was wielded by the women of the forgotten past.« (März 1859: 6) Daran, dass Margarete von Norwegen (13531412) in ihrer Zeit eine bedeutende und machtvolle Herrscherin war, lässt der Artikel keinen Zweifel: »How these rude Northmen came afterwards to be both governed and subdued by a woman; [...] how, driven from all their strongholds of pride and prejudice, they were made to bow lower beneath that woman's yoke than ever their ancestors bowed in the old time before the priestesses of the temple, it is now our purpose to relate.« (März 1859: 8) Die Wiederholung des Wortes $»$ woman in dieser Passage unterstreicht, $\mathrm{zu}$ welch herausragenden politischen Leistungen das >schwache< Geschlecht fähig war, und dass Macht und 
Weiblichkeit einander nicht ausschlossen. Im Gegenteil, so betont Edwards, führte in Fall Margaretes gerade die Kombination >männlicher $<$ und > weiblicher< Eigenschaften zu einem Glücksfall für ganz Skandinavien. ${ }^{28}$ Umso >merkwürdiger $<$ und >bedauernswerter sei es, dass auch eine derart herausragende Figur von der offiziellen Geschichtsschreibung vergessen wurde, und zwar, so kann man zwischen den Zeilen lesen, aufgrund ihres Geschlechts: »Very strange is it, and much to be regretted, that no circumstantial history of this reign has been handed down to posterity. [...] we are not aware that any attempt has yet been made to present a connected narrative of her life.« (April 1859: 95) Ihr Artikel präsentiert sich so als erster Schritt, die Königin Margarete wieder in die kollektive Erinnerung und die Historiographie einzuschreiben.

Neben Herrscherinnen porträtierte das $E W J$ wie andere Frauenzeitschriften eine große Bandbreite bemerkenswerter historischer Frauen: Gelehrte und wohltätige Frauen ${ }^{29}$ oder Intellektuelle wie Mme de Staël und Rahel Varnhagen. ${ }^{30} \mathrm{Ge}-$ rade für die intellektuellen Frauen des späten 18. und frühen 19. Jahrhunderts wird insistiert, dass sie mit ihren Zirkeln auf ihre Art Macht ausübten. So spricht ein Artikel »Madame de Staël« eine »almost magical influence during this stormy period of society « zu und erklärt den Salon zu einem »empire, in which women were all-powerful« (Bd. 9/54, August 1862: 365).

Das EWJ stellte aber auch Frauen vor, die Gewalt und Ungerechtigkeit erdulden mussten wie Agnes Bernauer, ${ }^{31}$ solche, die der Französischen Revolution zum Opfer gefallen waren, ${ }^{32}$ oder Mitstreiterinnen der Revolution von 1848/49 wie Johanna Kinkel, die mit ihrem Mann ins englische Exil gegangen war. ${ }^{33}$ Bri-

28 »To that force of character and steadiness of judgement which more frequently belongs to man, she added the persuasive eloquence and subtle fascinations which are supposed to be the legitimate weapons of her sex. She was ambitious without seeming to be so, and achieved greatness while appearing only to follow the dictates of circumstance.« (EWJ, April 1859: 94)

29 »Margaret Beaufort«, EWJ, Bd. 8/43, September 1861 und 44, October 1861; »Sketch of the Life and Labours of Maria Bocci La Moinette«, EWJ, Bd. 3/16, Juni 1859; »Amalie Sieveking«, EWJ, Bd. 5/25, März 1860; »Elizabeth, Princess Palatine«, EWJ, Bd. 9/50, April 1862 und 51, Mai 1862.

30 Zum Beispiel »Maria Edgeworth«, EWJ, Bd. 7/2, September 1858; »Bettina [von Arnim]«, $E W J$, Bd. 3/15, Mai 1859; »Rahel [Varnhagen]«, EWJ, Bd. 3/17, Juli 1859.

31 »Agnes Bernauerin«, 3 Teile, EWJ, Bd. 12/67, August 1863 bis 69, Oktober 1863.

32 Zum Beispiel »Marie Antoinette and the Court of France«, EWJ, Bd. 12/69, November 1863 und 70, Dezember 1863.

33 »Johanna Kinkel«, EWJ, Bd. 2/11, Januar 1859, ist ein Nachruf. 
1

tische Sympathien speziell für das italienische Risorgimento mögen erklären, warum das $E W J$ ein besonderes Interesse für italienische Frauen zeigte - auch jenseits der Unabhängigkeitsbewegung. So vermerkte ein Artikel, dass Italien eine lange Tradition gelehrter und künstlerischer Frauen vorzuweisen habe, einschließlich Professorinnen an Universitäten. ${ }^{34}$ Auch >exzentrischen $<$ Frauen zollte das $E W J$ Respekt. In einem zweiteiligen Beitrag 1862 würdigte es differenziert die für ihr freiwilliges orientalisches Exil notorisch gewordene Lady Hester Stanhope (1776-1839). ${ }^{35}$ Und in zumindest einem Fall wurde eine legendäre südasiatische, nichtchristliche Herrscherin als vorbildlich dargestellt: Im Juni 1863 findet sich im EWJ unter dem Titel »The Story of an Indian Princess « (Bd. 11/64) die Lebensgeschichte der Alia Bhye (Ahilyabai Holkar), die in der zweiten Hälfte des 18. Jahrhunderts über das indische Königreich Malwa herrschte und ihm Frieden und Wohlstand brachte.

Als Zeitschriften aus der Frauenbewegung präsentierten das EWJ und VM die Geschichte von Frauen facettenreich und mit einer feministischen Perspektive. Von den nicht-feministischen Zeitschriften für Frauen wichen sie dabei meist graduell und nicht grundsätzlich ab. Der feministische Gestus beider Publikationen auch in der Darstellung von Geschichte war begrenzt durch die Situation der bürgerlichen Frauenbewegung in Großbritannien, die ihre Ziele nicht konfliktuell, sondern im Kontext allgemeiner Reformbestrebungen und ohne Verletzung bürgerlicher Wertvorstellungen erreichen wollte. Bei allen Veränderungen, die vor allem für Frauen der mittleren Schichten erreicht werden sollten, operierte die bürgerliche Frauenbewegung in Großbritannien vor 1890 daher auch mit Rücksicht auf das in ihren Kreisen noch dominante Ideal häuslicher Weiblichkeit. Dieser Umstand schlägt sich auch in den ersten Schritten der Selbsthistorisierung der Bewegung nieder, die sich anhand der Englishwoman's Review nachvollziehen lassen.

\section{Selbsthistorisierung der Frauenbewegung}

Wie bereits festgestellt wurde, war die $E R$ stark gegenwartsbezogen; sie machte aber wiederholt Rückblicke, oft motiviert durch Erfolge, die nach zehn oder zwanzig Jahren des Kampfes endlich erreicht wurden, wie z.B. beim Zugang von

34 »Gallery of Illustrious Italian Women«, $E W J$, Bd. 1/6, August 1858 bis Bd. 2/10, Dezember 1858.

35 »Lady Hester Stanhope«, EWJ, Bd. 9/52, Juni 1862 und 53, Juli 1862. Erst deutlich später, im Februar 1881, druckte das nichtfeministische Ladies' Treasury eine Biographie Stanhopes unter dem Titel »A Celebrity of the Present Century«. 


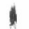

Frauen zum Arztberuf oder bei den Fortschritten in der Ehegesetzgebung. ${ }^{36} \mathrm{Am}$ 15. August 1878 (Bd. 9/64) erschien im ER der Artikel »Three Decades of Progress «, der 30 Jahre Frauenbewegung in den USA zum Anlass nahm, die eigene Situation zu analysieren. 1848 war in Amerika nicht nur Margaret Fullers programmatische Schrift Woman in the Nineteenth Century erschienen, sondern in diesem Jahr fand auch der als Auftakt der amerikanischen Frauenbewegung gewertete Kongress von Seneca Falls statt. Der Artikel im ER hält fest: »Our friends beyond the Atlantic have been celebrating the third decade of the movement for the advancement of women. This movement really dates a few years earlier in America owing to the attention excited by the publication of Margaret Fuller's remarkable work [...]« (337) Die britische Frauenbewegung habe dagegen nicht nur später begonnen, sie sei in ihrem Charakter auch weniger antagonistisch als die amerikanische: »The efforts of the >Women's Progress< party in England have always been directed towards increasing their power of effectively co-operating with men, and establishing joint, but not antagonistic rights [...].« (338) Explizit angesprochen wird die Scheu der britischen Bewegung vor $\mathrm{zu}$ schnellen und drastischen Interventionen in die dominante Geschlechterordnung: »Our progress during the parallel course of thirty years has been made with slow and very cautious steps.« (Ebd.) Trotz dieser Selbsteinsicht dokumentiert eine Chronologie am Ende des Artikels stolz die Schritte der britischen Bewegung, einschließlich der Gründung des $E W J$ - noch vor der Gründung des ersten Londoner Damenschwimmbads.

Die Vorsicht der britischen Bewegung und ihre Rücksicht auf bestehende Weiblichkeitsideale erklärt eine signifikante Lücke der Selbsthistorisierung. Die Amerikanerin Margaret Fuller konnte anlässlich der zehnten Wiederkehr ihres tragischen Todes durch Ertrinken im EWJ mit einem zweiteiligen Artikel als Ikone der Bewegung gewürdigt werden, weil sie trotz aller feministischer Forderungen in ihrem Privatleben die Grenzen >respektabler Weiblichkeit gewahrt hatte. ${ }^{37}$ Geradezu verschwiegen wurde im EWJ wie im VR dagegen Mary Wollstonecraft, die Autorin der Vindication of the Rights of Woman (1792) - obwohl sie keineswegs eine > vergessene< Frau der Geschichte war und andernorts Beachtung fand, etwa durch die Schriftstellerin George Eliot, die in einem Aufsatz

36 »History of the >Married Women's Property< Bill«, ER, Bd. 4/15, Juli 1873; »The Twentieth Anniversary of the Foundation of the Society for the Employment of Women«, ER, Bd. 10/75, Juli 1879; »The Close of a Long Struggle«, ER, Bd. 8/48, April 1877.

37 »Life of Margaret Fuller Ossoli«, EWJ, Bd. 4/19, September 1859 und 20, Oktober 1859. 
1

für die Zeitschrift The Leader Fuller und Wollstonecraft schon 1855 verglichen hatte. ${ }^{38}$ Für die bürgerlich-feministischen Zeitschriften war Wollstonecraft aber offensichtlich prekär: Eine Bewegung, die die Grenzen der viktorianischen Geschlechterordnung weitgehend wahren wollte, konnte sich über eine politisch radikale Atheistin, die einen distinkt unhäuslichen Lebensstil gepflegt hatte, nicht identifizieren oder gar legitimieren. Wollstonecrafts Wiederentdeckung durch die englische Frauenbewegung ließ allerdings nicht mehr lange auf sich warten. Eine Notiz im Ladies' Treasury vom November 1890 in der Rubrik »On-Dits and Facts of the Month « erwähnt einen Vortrag der Frauenrechtlerin Florence Balgarnie (1856-1928) über »The Emancipation of Women«, in dem diese prophezeite, dass die Zeit kommen werde, »when the women of England, perhaps the women of the world, would realise that Mary Wollstonecraft was the first to strike a blow for the emancipation for her sex, and would raise a monument to her memory. « (703) In der Hochphase der Frauenbewegung um die Jahrhundertwende fand diese Monumentalisierung dann auch in Frauenzeitschriften statt, und zwar nicht nur in biographischen Artikeln: 100 Jahre nach Wollstonecrafts Tod wurde ihre Vindication 1897/98 in der feministische Zeitschrift Woman's Signal (1895-99) als Serie wieder abgedruckt und damit auch jenen Frauen zugänglich gemacht, die sich eine Buchedition nicht leisten konnten.

Wie das folgende Kapitel zeigt, wies die Frauenbewegung aufgrund der politischen Verhältnisse in den deutschen Staaten einige Unterschiede zur zeitgenössischen englischen Situation auf, doch lässt die Analyse der feministischen deutschen Frauenzeitschriften auch Parallelen erkennen.

\section{DAS DEUTSCHE BEISPIEL}

\section{Frauenbewegung in den deutschen Staaten und ihre Zeitschriften}

In den deutschen Staaten formierte sich seit Mitte der 1840er Jahre im Kontext oppositioneller, nationaler und religiöser Reformbewegungen die frühe deutsche Frauenbewegung, die in den Jahren der Revolution von 1848/49 ihren Höhepunkt erreichte (Gerhard 1990: 42-75, Paletschek 1998: 16-24; Gerhard 2004: 106-108; Schaser 2006: 15-23). Der liberal-demokratische Aufbruch dieser Jahre beförderte die schon im Vormärz einsetzende Politisierung von Frauen vornehmlich der bürgerlichen und zum Teil auch kleinbürgerlichen Schichten. Es gründe-

38 »Margaret Fuller and Mary Wollstonecraft«, The Leader, Bd. 6/290, 13. Oktober 1855: 988-989. 
ten sich erste Frauenvereine, die nicht nur die politische und religiöse Oppositionsbewegung unterstützten, sondern davon ausgehend erste feministische Forderungen - nach Teilnahme am politischen Leben, nach verbesserten Bildungsund Erwerbsmöglichkeiten von Frauen - stellten. Mit der von Louise Otto herausgegebenen Frauen-Zeitung erschien seit 1849 bis zur ihrem Verbot 1852 eine erste feministische Zeitschrift (Nachdruck Gerhard u.a. 1979). Zentren dieser frühen Frauenbewegung lagen in den mitteldeutschen Staaten, allen voran in Sachsen, aber auch im Rhein-Main-Raum, in Franken, in Schlesien, in Baden oder in einer Großstadt wie Hamburg. Mit der nach Niederschlagung der Revolution im Sommer 1849 einsetzenden politischen Repressionen in den deutschen Staaten kam bis 1852 auch diese frühe Frauenbewegung zum Erliegen. Die Frauen-Zeitung, ebenso wie einige der Frauenvereine oder auch die von ihnen gegründeten Kindergärten wurden als politisch zersetzend und die Ordnung gefährdend verboten. Viele der frühen Feministinnen, die meist gleichzeitig auch in der revolutionären Bewegung oder als religiöse Dissidentinnen aktiv waren, gingen ins Exil, nach London, in die Schweiz oder die USA.

Nach der politischen Stagnation in der Reaktionsära der 1850er Jahre formierte sich mit den sich ab 1859 liberalisierenden Verhältnissen in den deutschen Staaten auch die Frauenbewegung wieder neu, wobei ehemalige, bereits in den 1840er Jahren aktive Frauenrechtlerinnen eine wichtige Rolle spielten. 1865 entstand, etwa zeitgleich mit den ersten Parteien der Arbeiterbewegung, der Allgemeine Deutsche Frauenverein (ADF) in Leipzig, gegründet von der ehemaligen 1848erin Louise Otto-Peters (1819-1895) sowie Auguste Schmidt (18331902) (Gerhard 1990: 76-83; Gerhard 2004: 108-109). In der Folgezeit bildeten sich über die in unterschiedlichen Städten veranstalteten Frauentage Zweigvereine in den verschiedenen deutschen Staaten; 1877 schätzte Louise Otto, dass der ADF ca. 12000 Mitglieder hatte (Schaser 2006: 41). Ziele dieses über Zweigvereine national verbreiteten Frauenvereins waren eine Verbesserung der weiblichen Bildung, der Erwerbsmöglichkeiten für Frauen, ihrer Stellung in Recht und Gesellschaft sowie eine organisierte, vor allem Frauen zugutekommende Wohltätigkeit. Organ des $\mathrm{ADF}$ war die Zeitschrift Neue Bahnen, die bis in die 1890er Jahre hinein das wichtigste Sprachrohr der deutschen Frauenbewegung war. In den 1890er Jahren setzte die Hochphase der Bewegung ein, die mit einer enormen Verbreiterung - um 1913 hatte die deutsche Frauenbewegung ca. 500000 Mitglieder - sowie Zentralisierung und Ausdifferenzierung einherging. 1894 wurde als neuer Dachverband der Bund Deutscher Frauenvereine (BDF) gegründet; bis dahin hatte der ADF mit seinem >allgemeinen Anspruch gewissermaßen die gesamte Frauenbewegung vertreten (Stoehr 1990: 3). Nun bildeten sich verschiedene Stränge der Frauenbewegung heraus, so die proletarische bzw. sozial- 
demokratische, die radikale, die sich aus der sogenannten gemäßigten bürgerlichen Bewegung abspaltete, sowie die konfessionellen, d.h. die protestantischen, katholischen und jüdischen Frauenverbände. Seit den 1890er Jahren entwickelte sich ein breites Spektrum feministischer Zeitschriften, die den unterschiedlichen Flügeln der Frauenbewegung zugeordnet waren. Damit verbunden war auch ein Generationswechsel, d.h. die Pionierinnen der 1840er bis 1860er Jahren traten nun ab und eine neue Generation entwickelte neue Aktionsformen und -felder.

Im Folgenden untersuchen wir am Beispiel der Neuen Bahnen für den Zeitraum von 1865 bis Ende der 1890er Jahre die in der (später so genannten >gemäBigten $<$ bürgerlichen) deutschen Frauenbewegung entworfenen Geschichtsbilder und deren Umgang mit Geschichte. Die Neuen Bahnen wurden von Louise OttoPeters und Auguste Schmidt redigiert. Sie erschienen zweiwöchentlich, wurden von den Mitgliedern des Vereins automatisch bezogen, aber auch über den Buchhandel vertrieben. Es kann davon ausgegangen werden, dass die Zeitschrift eine Großzahl der in der Frauenbewegung aktiven bzw. mit dieser sympathisierenden Frauen (und Männer) erreichte. ${ }^{39}$

Mit den 1860er Jahren begann auch in Deutschland - mit leichter Verzögerung gegenüber England - das Zeitalter der Massenpresse. Zeitungen und Zeitschriften unterschiedlicher inhaltlicher Couleur und politischer bzw. religiöser Ausrichtung erreichten ein breites, bis in untere soziale Schichten reichendes und beide Geschlechter und alle Altersgruppen umfassendes Publikum. Ein kleines Segment dieser neuen Öffentlichkeit waren die von politischen Bewegungen, so auch der Frauenbewegung, herausgegebenen Zeitschriften. Die Herausgeberinnen der Neuen Bahnen versuchten, möglichst viele Abonnenten und Abonenntinnen zu werben und riefen immer wieder dazu auf, »dass Alle, denen es ernstlich darum zu thun ist, den Kreis des Frauenlebens in Bezug auf Bildung und Erwerb, Pflicht und Recht zu erweitern, es als Gewissenssache betrachten, unserm Blatt zu immer größerer Verbreitung zu helfen.« (Bd. 9/24, 1875: 192, Herv. i. O.)

Das Ziel des ADF und der Neuen Bahnen war die ökonomische und geistige Befreiung der Frau, wobei neben der Eröffnung neuer Berufsfelder für Frauen

39 Louise Otto und Auguste Schmidt trugen durch einen Vielzahl von Artikeln zu den Neuen Bahnen bei. In der Zeitschrift publizierten in der Bewegung aktive Frauen wie z.B. Julie Engell-Günther, Luise Büchner, Thekla Naveau, Natalie von Milde, Anna Simon etc. Es erschienen daneben auch anonyme oder mit den Anfangsbuchstaben gekennzeichnete Artikel. Männliche Autoren steuerten ebenso, allerdings mit einem deutlich kleineren Anteil, Artikel bei. In den Neuen Bahnen wurden auch die Leserinnen (und Leser) immer wieder zur Einsendung von Beiträgen aufgefordert. 
11

der weiblichen Erziehung - über die Errichtung von Gewerbeschulen, höheren Mädchenschulen bis zur Öffnung der Universitäten - eine besondere Bedeutung zukam. Zentrales Diktum der Bewegung bis in die 1890er Jahre hinein war das Eintreten für »das Menschenthum der Frau « (NB, Bd. 30/17, 1895: 180), d.h. die ganzheitliche Überzeugung, dass die Frauenfrage eine Menschheitsfrage sei. Nur durch eine verbesserte Stellung der Frau, die ihr die Entfaltung all ihrer Anlagen und Kräfte ermöglichte, könnten sich die gesellschaftlichen und sozialen Missstände grundsätzlich bessern.

Sucht man nach Vergangenheitsbezügen in den Neuen Bahnen im Zeitraum zwischen 1866 und 1900 so ist das erste Ergebnis ernüchternd im Vergleich mit der bereits erwähnten Präsenz von Geschichte in britischen Frauenzeitschriften oder dem großen Anteil, den historische Themen in der beliebten Familienzeitschrift Die Gartenlaube einnahmen (Paletschek 2011: 41 und zu Familienzeitschriften allgemein Korte/Paletschek 2012). Die Neuen Bahnen berichteten auf den ersten Blick fast nur - und hier scheinen sie am ehesten vergleichbar mit der seit 1866 erscheinenden Englishwoman's Review zu sein - über die Entwicklung in den Vereinen, über Petitionen und allgemeine Fragen wie Frauenstudium, Berufsbildung, die Öffnung neuer Berufszweige oder den Fortgang der Bewegung im Ausland. Dies entsprach der politischen Ausrichtung der Zeitschrift, die sich nur mit ernsthaften Fragen beschäftigen wollte und anlässlich ihres 25-jährigen Jubiläums stolz von sich behauptete, die einzige Frauenzeitung zu sein, die trotz ihres langen Bestehens »nie in ihren Spalten etwas Novellistisches, einen Modenbericht oder ein Kochrezept « gebracht habe. ${ }^{40}$ Die Neuen Bahnen grenzten sich damit dezidiert gegenüber Familienzeitschriften und anderen, nichtfeministischen Frauenzeitungen ab. Geschichte schien, so könnte zunächst vermutet werden, in die Sparte Unterhaltung und Novellistisches zu fallen, von der sich die Neuen Bahnen klar distanzierten. Zwar erschienen in den Neuen Bahnen nur wenige explizit historischen Themen oder Biographien gewidmete Artikel, doch fanden sich bei näherem Hinsehen - so in den Leitartikeln, in den Bücher-

40 Auguste Schmidt: »Das zweite Vierteljahrhundert«, NB, Bd. 26/1, 1891: 1-3, zit. 3. Auguste Schmidt fährt fort: »Wir wollen durch dieses negative Verdienst keinesweges den trefflichen Hausfrauen- und Modezeitungen zu nahe treten, die zur Bildung guter Hausfrauen und zur Verfeinerung der Geschmacksrichtung viel beigetragen haben, aber daß eine Frauenzeitung 25 Jahre alt und noch weiter lebensfähig sein kann, ohne daß sie dem Interesse der Küche und der Mode die geringsten Zugeständnisse macht, - das erscheint doch jedem, der das Leben aufmerksam beobachtet, wie ein Wunder, ja - wie ein Wunder, welches uns voraussetzen läßt, daß auch die Frauen lernen werden, sich mit allgemeinen Lebensaufgaben zu beschäftigen.« 
empfehlungen oder in Jubiläumsrückblicken - überraschend viele historische Bezüge.

\section{Teleologische Fortschritts- und Emanzipationsgeschichte: Aus der Geschichte lernen}

Eine aufklärerische Fortschrittsgeschichte bestimmte das Geschichtsbild in den Neuen Bahnen. Aus der Geschichte könne gelernt werden, es gehe das »Heute aus dem Gestern« und »das Morgen aus dem Heute « hervor, schrieb Auguste Schmidt in ihrem Artikel »Zur Erkenntnis der Zeit« (Bd. 5/20, 1870: 154). Durch die Beschäftigung mit Geschichte könne die Gegenwart besser verstanden und die Zukunft antizipiert werden. Die Zeitschrift vertrat die Überzeugung, dass sich die Menschheit in steter Fortentwicklung befinde. In der Kulturgeschichte zeige sich ein »Gesetz des Fortschritts und Emporkommens«, »das Emporsteigen zu sittlicher Anschauung und Grundsätzen«. Laut einer historischen Buchempfehlung übt der historische Rückblick »eine versöhnende Kraft auf die Gegenwart« aus und deswegen sei es auch für die Frauen »dringend geboten, sich mit Culturgeschichte zu beschäftigen «. ${ }^{41}$

Mit dieser Vorstellung vom steten sittlichen Fortschreiten der Geschichte war die Überzeugung verbunden, dass sich damit die Forderungen der Frauenbewegung in ferner Zukunft verwirklichen würden, da die Frauenfrage ja als Menschheitsfrage dem sittlichen Fortschritt diente. In Zeiten der Reaktion könne eine Flucht in die Geschichte helfen, die Zeit des Stillstands zu überwinden, schrieb Louise Otto und führte als Beispiel sich selbst und ihre Beschäftigung mit Geschichte in der Reaktionsphase der 1850er Jahren an:

»Alle Fortschrittsbestrebungen - auch die Frauenbewegung waren gehemmt. Die >Frauenzeitung< [sic], die ich 1849 gegründet, konnte nicht weiter erscheinen - auch sonst war mir die Gegenwart für mein Schaffen verleitet. Ich flüchtete in die Vergangenheit! [...] Zu den Beschäftigungen mit der Hexenzeit trieb mich nicht allein meine Weltflucht - oder meine Vorliebe für Mittelalter und Romantik - es trieb mich auch dazu: Die Frauenfrage.«(Bd. 26/5, 1891: 34) 
1

Aus ihrer Beschäftigung mit der Hexengeschichte zog Louise Otto den Schluss, dass man niemals denken dürfe, »der Unsinn müsse in und von sich selbst zerfallen! - das geschieht nicht, es muß dagegen gekämpft werden. ${ }^{42}$

Für die Beurteilung der Gegenwart stellte die Geschichte einen Erfahrungshaushalt dar der half, mögliche Entwicklungslinien abzuschätzen - im Positiven wie im Negativen. So dämpfte Louise Otto-Peters in ihrem Artikel »Die neue Zeit« angesichts des Sieges im deutsch-französischen Krieg 1870 und der nachfolgenden Reichsgründung die nationale Euphorie. Sie warnte davor, dass »Deutschlands so heiß ersehnte Einigkeit und Größe mit einer Säbeldictatur Hand in Hand geht, die dem Volkswohl niemals förderlich war « und dass sich das deutsche Volk »nicht abermals wie nach der Erhebung 1813 um die nur an der Sonne der Freiheit reifende Frucht des Sieges werde betrügen lassen« (Bd. 5/22, 1870: 170).

Dass sich gerade Frauen mit Geschichte beschäftigen sollten, wurde in den Neuen Bahnen mehrfach betont. Frauen könnten »Gleichberechtigung weder erhalten noch beanspruchen dürfen, bis sie nicht selbst über die Hauptgebiete der Menschheitsentwicklung einen klaren historischen Überblick gewonnen haben« (Bd. 6/11, 1871: 80). Zudem sei es Aufgabe der Frauen und Mütter, dem Kind über Sagen und Geschichtserzählungen ein Nationalgefühl zu vermitteln (Bd. 1/10, 1866: 75) - d.h. aus nationalen wie feministischen Erwägungen heraus erschien eine Geschichtskenntnis für Frauen unabdingbar. Die Kenntnis der deutschen Geschichte sei gerade für Frauen und die weibliche Jugend wichtig, da »in Folge der langjährigen Zersplitterung Deutschlands unsern Frauen im Allgemeinen noch so sehr das Verständniß für die Entwicklung ihres Vaterlandes « fehle so 1875 der Kommentar zur Empfehlung des Buches Deutsche Geschichte von 1815-1870 von Luise Büchner. Das Buch wurde den Leserinnen und Lesern wärmstens ans Herz gelegt, da es eines der wenigen historischen Werke einer Frau sei und zudem in populärer Form eine übersichtliche und gedrängte Darstellung der historischen Entwicklung gebe (Bd. 10/4, 1875: 111).

42 Louise Otto: »Mahnungen aus der Hexenzeit«, in: NB, Bd. 26/5, 1891: 33-36, zit. 34. Louise Otto schrieb in den 1850er Jahren »Hexengeschichten nach den Quellen«; sie arbeitete dafür in der Dresdner Königlichen Bibliothek mit dem Hexenhammer und weiteren Hexenchroniken. Die Artikel erschienen in verschiedenen Zeitschriften, wurden vielfach wieder abgedruckt und in ihrem Band Aus der alten Zeit (Leipzig: Hübner, 1871) sowie in ihren Privatgeschichten aus der Weltgeschichte (Leipzig: Mathes, 1868) publiziert. 
1

\section{Historische Vorbilder: (herausragende) Frauen, Freiheitsbewegungen und ihre Helden}

Wer tummelte sich in dem in den Neuen Bahnen konstruierten historischen Universum der Frauenbewegung? Es handelt sich, wie zu erwarten, vielfach um historische Frauengestalten: verfolgte Hexen, Philosophinnen der Antike, ${ }^{43}$ Astronominnen der Frühen Neuzeit, gebildete Fürstinnen vom Mittelalter bis zur Gegenwart, ${ }^{44}$ Frauen der Reformation, des Humanismus und der Befreiungskriege sowie erste promovierte Frauen wie Dorothea Schlözer, Charlotte von Siebold und Nadežda Suslova. ${ }^{45}$ Auch wurde den Leserinnen und Lesern die Geschichte der Freiheits- und Revolutionsbewegungen der Neuzeit, insbesondere der englischen, amerikanischen und französischen Revolution oder auch die Geschichte der Freimaurerei ans Herz gelegt. ${ }^{46}$

43 Siehe etwa die Serie »Philosophinnen des Alterthums« von F.M. Wendt, $N B, \mathrm{Bd}$. 9/18, 19, 20, 22, 24, 1874. Behandelt wurden Theano, Hipparchia, Arete, Axiothea, Lasthenia, Themista, Arria, Julia Domna, Salonina, Asklepigeneia, Aedesia, Sofiapatra, Hypatia. Der Autor der Serie F.M. Wendt aus Hermannstadt war Lehrer und Psychologe. Er unterrichtete am Lehrerinnenseminar von Auguste Schmidt in Leipzig, später war er Professor am k.k. Staatsinstitut zur Bildung von Lehrern und Lehrerinnen in Troppau (österreichisches Schlesien). Eine seiner Töchter war die österreichische Frauenrechtlerin, Schriftstellerin und Lehrerin Irene Sponner-Wendt (18671922), die andere Tochter, Cäcile Böhm-Wendt (1875) promovierte als eine der ersten Frauen 1900 in Wien in Mathematik. Siehe u.a. (http://www.onb.ac.at/ariadne/vfb /bio_sponner.htm).

44 Auguste Schmidt: »Fürstliche Frauen«, NB, Bd. 33/19, 1898: 201-203.

45 Siehe u.a. den Artikel »Drei weibliche Doctor-Promotionen«, NB, Bd. 3/5, 1868: 3335; behandelt werden hier Dorothea Schlözer, 1787 promoviert, Charlotte von Siebold, 1818 promoviert, sowie Nadežda Suslova, die 1868 in Zürich promoviert wurde. Siehe ferner auch die folgenden Artikel: Else Oelsner und Auguste Schmidt: "Die Leistungen der deutschen Frau in den letzten 400 Jahren auf wissenschaftlichem Gebiete«, NB, Bd. 29/12, 1894: 89-90; Amanda Georgi: »Sternkundige Frauen«, NB, Bd. 30/16, 1895: 121-123; Amanda Georgi: »Der Frauen Antheil an Gestaltung und Erhaltung der urgermanischen Volksdichtung und ihrer Sagenstoffe «, NB, Bd. 30/11, 1895: 81-83. Buchbesprechungen gab es u.a. zu Auguste Scheibes Caroline Herschels Memoiren und Briefwechsel, 1750-1848, NB, Bd. 12/23, 1877: 183, und Die Frauen des achtzehnten Jahrhunderts, NB, Bd. 12/12, 1877: 95-96.

46 L.O.: »Ein Jahrhundert der Revolutionen von Ludwig Wittig«, NB, Bd. 10/11, 1875: $88 ; »$ Geschichte der Freimaurerei «, NB, Bd. 6/11, 1871: 79-80. 
Auffällig ist die Aufmerksamkeit der Neuen Bahnen für die zeitgeschichtlichen, nur wenige Jahre zurückliegenden nationalen Unabhängigkeitsbewegungen: Die Helden der italienischen Einigungsbewegung, Garibaldi, Mazzini oder Piero Cironi, ${ }^{47}$ sowie der Revolution von 1848/49 - ein ähnlicher Befund ist auch für die britischen Zeitschriften der Frauenbewegung zu verzeichnen - fanden besondere Aufmerksamkeit. Aber auch mit der Freimaurerbewegung - »eine ideale Föderation, innerhalb derer Gleichberechtigung Aller [...] ungeschmälerte Geltung « fand (Bd. 6/11, 1871: 80) - sollten sich die Leserinnen und Leser beschäftigen. Der Fokus lag zwar bevorzugt auf der deutschen nationalen historischen Entwicklung, dabei wurde aber keineswegs ein national begrenztes Geschichtsprogramm entworfen. Die vorbildhaften Personen waren überwiegend, doch nicht ausschließlich historische Frauengestalten, sondern ebenso Männer, insbesondere Freiheitshelden oder männliche Vorkämpfer der Frauenemanzipation wie Theodor Gottfried von Hippel. ${ }^{48}$ Historische Vorbilder waren also gleichermaßen russische Medizinerinnen, französische Astronominnen, italienische Freiheitskämpfer, griechische Philosophinnen oder rumänische Dichterköniginnen.

Zudem fällt die antikatholische, antiklerikale und protestantische Einfärbung des Geschichtsbildes in den Neuen Bahnen auf: Luther wird als Vorkämpfer der Frauenemanzipation, als erster Gründer systematischer Mädchenschulen gefeiert und zur Legitimation der zeitgenössischen Emanzipationsforderungen herangezogen. Würde Luther in der Gegenwart noch leben, so Auguste Schmidt in ihrem Artikel »Luther und die Erziehung der Mädchen« (Bd. 11/1, 1876: 2-4), würde er, ebenso wie er in seinem Jahrhundert die religiösen Missstände kritisiert habe, nun die ökonomischen und geistigen Beschränkungen der Frauen aufs Schärfste geißeln.

Dass sich Frauen in der deutschen Geschichte auskennen sollten, war ein Anspruch, den die Herausgeberinnen der Neuen Bahnen an ihre Leserinnen stellten. Unter deutscher Geschichte wurde dabei vornehmlich die Geschichte der Nationalbewegung verstanden. Deutsche Geschichte war noch nicht auf Preußen fokussiert. Statt dessen wurde das Studium der sächsischen oder badischen Geschichte empfohlen, da diese Staaten in der Verwirklichung von Verfassung und

47 Die italienischen Freiheitskämpfer gehörten »nicht Italien allein [...], sondern der ganzen Menschheit« und alle Nationen sollten sich vereinigen, sie zu lieben und zu ehren. So die Buchbesprechung zu Ludmilla Assings Piero Cironi: Ein Beitrag zur Geschichte der Revolution in Italien, NB, Bd. 3/15, 1868: 119-120.

48 L.O.: »Zum 150. Jubiläum eines Schriftstellers für das Frauenrecht«, NB, Bd. 26/7, 1881: 50-51. 
Frauenrechten - so etwa durch die erstmalige Abschaffung der Geschlechtsvormundschaft in Sachsen 1831 - vorangegangen seien: »Sachsen leuchtete in der Reformation voran und Sachsen war auch nächst Baden der fortschrittlichste Staat in Bezug auf Verfassung und Rechtspflege. Speciell auch auf die Stellung der Frauen. In Sachsen ward bereits 1831 die Geschlechtsvormundschaft aufgehoben [...] (Bd. 9/24, 1874: 192).

\section{Intentionale Geschichte}

In den Neuen Bahnen konzentrieren sich die historischen Themen auf die - damalige - Zeitgeschichte, d.h. die Jahre seit der Französischen Revolution und damit auf die Jahre, die in die Zeitspanne des kommunikativen Gedächtnisses oder der Mitlebenden fielen. Während Staatengeschichte weitgehend fehlte, finden sich neben geistes- und ideengeschichtlichen .Themen - die sich meist auf die geistigen und literarischen Leistungen von Frauen konzentrierten - Ansätze einer Behandlung von Technik-, Wirtschafts- und Sozialgeschichte, etwa eine Geschichte der Nähmaschine (Bd. 1/10, 1866: 75-76) oder der Seidenraupenzucht (Bd. 5/3, 1870: 17-20). In diesen Beispielen zeigt sich die Anbindung der historischen Themen an die Lebenswelt und mögliche Arbeitsbereiche der Leserinnen.

Insgesamt ist die Darstellung durch einen stark intentionalen Zugriff auf Geschichte gekennzeichnet: Die Geschichte der Freiheits- und Revolutionsbewegungen wird als Teil der eigenen Geschichte begriffen. Der Verweis auf die geistigen und wissenschaftlichen Leistungen historischer Frauengestalten diente da$\mathrm{zu}$, die Bildungsforderungen der Gegenwart zu untermauern und »das Gerede von der Unfähigkeit der Frauen für den Eintritt in das Reich der Wissenschaft niederzuschlagen « (Bd. 12/23, 1877: 184). Zuschreibung feministischer Forderungen an berühmte Männer der Weltgeschichte wie z.B. Luther legitimierten die eigenen Forderungen der Gegenwart und stellten diese perspektivisch in eine sittliche Erfolgs- und Fortschrittsgeschichte der Menschheit. Es wurden vornehmlich historische Werke von Männern und Frauen der >Bewegung <, häufig ehemaligen 1848ern, besprochen und zur Lektüre empfohlen. Wenn es sich um Bücher zur Geschichte herausragender Frauen handelte, die von konservativen Autorinnen geschrieben worden waren, wurden diese deutlich kritischer besprochen. So sei etwa Fanny Arndts ${ }^{49}$ Der Frauen Antheil an der modernen Weltge-

49 Fanny Arndt war eine preußische Schriftstellerin und Historikerin, die auf dem populären historischen Buchmarkt erfolgreich mit zahlreichen Schriften vertreten war (Nissen 2009: 77). 
in

schichte zwar nicht in der Absicht der Frauenbewegung geschrieben worden, habe ihr aber dennoch gedient. Arndts Fazit, dass sich Frauen selten zum Besten des Landes in die Politik eingemischt hätten, da ihr Versöhnungstrieb hinter der Lust an der Intrige zurückgestanden sei, müsse man nicht unbedingt zustimmen. Die von Arndt als lobende Beispiele angeführten Regentinnen bewiesen jedoch, dass Frauen, würde man sie nur lassen, nicht zum Mittel der List greifen müssten und trefflich regieren könnten. Den Leserinnen und Lesern der Neuen Bahnen wurde also nahegelegt, die im Buch aufgeführten >Fakten< in einer kritischsubversiven Lesart zu einer anderen Geschichtsdeutung zusammenzufügen (Bd. 12/1, 1877: 7-8).

\section{Selbsthistorisierung seit den 1890er Jahren und sich wandelnde zeitliche Erwartungshorizonte}

In den Neuen Bahnen wurden, wie in der damaligen ebenso wie der heutigen Geschichtskultur üblich, Jubiläen als Erinnerungsanker benutzt. Zwar betonte Auguste Schmidt die Willkürlichkeit des 25-jährigen oder 30-jährigen Erinnerns (Bd. 26/1, 1891: 1); doch hinderte dies sie und ihre Autorinnen nicht daran, häufig davon Gebrauch zu machen. In Jubiläumsartikeln wurde die Geschichte der Frauenbewegung, lokaler Frauenbildungsvereine oder Mädchenschulen thematisiert. ${ }^{50}$ Seit den 1890er Jahren setzten eine Reflexion der eigenen Geschichte und eine Historisierung der Frauenbewegung ein, die mit dem 25- bzw. 30-jährigen Bestehen des ADF und der Zeitschrift selbst zusammenfiel. ${ }^{51}$ Diese Selbsthistorisierung lief parallel zur Verbreiterung der Frauenbewegung zu einer Massen-

50 Die Jubelfeiern selbst wurden >historisch< begangen: So war die Feier anlässlich des 25-jährigen Bestehens der Städtischen Höheren Schule für Mädchen in Leipzig von einer theatralen Aufführung »historischer Bilder«, die Frauen in der Reformation sowie in den Befreiungskriegen darstellten, begleitet ( $N B$, Bd. 31/21, 1896: 184). Heute würden wir dies unter Reenactment oder living history fassen.

51 Siehe u.a. Louise Otto: »Zum 25jährigen Bestehen des Frauenbildungsvereins Leipzig«, NB, Bd. 25/4, 1890: 25-29; Auguste Schmidt: »Das zweite Vierteljahrhundert«, NB, Bd. 26/1, 1891: 1-3; »Ein Artikel von Louise Otto aus dem Jahre 1847«, $N B$, Bd. 30/24, 1895: 193-195; Auguste Schmidt: »Die Entstehung und Bedeutung der Frauentage in Deutschland «, $N B$, Bd. 30/17, 1895: 179-180; Clara Claus: »Vor dreissig Jahren«, NB, Bd. 31/6, 1896: 50; Henriette Goldschmidt: »Wir sind die Alten«, $N B$, Bd. 31/6, 1896: 49; Henriette Goldschmidt: »Die Hochschule für das weibliche Geschlecht in Hamburg, gegründet 1850«, NB, Bd. 33/19, 1898: 197-200; Auguste Schmidt: »Die Zeit und wir!«, NB, Bd. 33/1, 1898: 1-2. 
bewegung, der Ausdifferenzierung der Bewegung und zum Aufkommen von Konkurrenz durch die proletarische, die konfessionelle, aber auch die sjunge Generation < der radikalen Frauenbewegung, die sich aus der >gemäßigten < bürgerlichen Frauenbewegung herauslöste.

Im historischen Rückblick in den Neuen Bahnen wurden die unterschiedlichen Generationserfahrungen und vor allem die Prägung der ersten Generation der Frauenbewegung durch die 1848er Revolution betont. Henriette Goldschmidt hob in ihrem Beitrag »Wir sind die Alten! « hervor, dass es ein Vorzug der Älteren sei (»wenn es je ein Vorzug genannt werden kann, älter zu sein als die Jugend «), dass sie den Aufbruch der 1840er Jahre miterlebt hätten. Wer diese Jahre bewusst erlebt habe, der sei ihr kein Fremder, sondern zu diesem habe sie eine innere Beziehung (Bd. 31/6, 1896: 49). Die 1860er Jahre und das Wiederaufleben der Frauenbewegung wurden retrospektiv als jene »ersten Zeiten des Sturmes und Dranges « (Bd. 33/10, 1898: 103) wahrgenommen. Es wird betont, wie groß die gesellschaftlichen Anfeindungen und der Charakter des Neuartigen der Frauenbewegung in diesen ersten Jahren waren (Bd. 30/17, 1895: 130). Die jetzige »junge« Frauenbewegung wolle von ihren Vorgängerinnen nichts wissen und erfinde das Rad vermeintlich neu. Doch seien lediglich die Geschwindigkeit, in der Veränderung erwartet würden und die Aktionsformen - Protestversammlungen statt gemeinnütziger Tätigkeit - andere, nicht aber die grundsätzlichen Forderungen, die alle schon einmal da gewesen seien - so Natalie von Milde in ihrer Bilanzierung »Alte und neue Frauenbewegung « (Bd. 33/23, 1898: 251).

In den 1890er Jahren setzte eine systematischere Beschäftigung mit der Geschichte der eigenen Bewegung ein. Es wurde versucht zu bestimmen, was tatsächlich neu an der organisierten Frauenbewegung der 1860er war und welche Stationen wichtig waren: Benannt wurden in den Neuen Bahnen als zentrale Wegmarken die Poesie, die Landtagsverhandlungen und die freireligiöse Bewegung des Vormärz, die Frauenvereine der Revolutionszeit, die Frauen-Zeitung Louise Ottos 1849-1852, die Hamburger Frauenhochschule 1850-1852 und schließlich die Vereinsgründung 1865 sowie die in unterschiedlichen Städten abgehaltenen Frauentage (Bd. 30/24, 1895: 193-195). Gleichzeitig wurde die Traditionslinie der Bewegung immer weiter nach hinten verlegt und durch »Thatemanzipierte « wie Hypathia oder astronomische Forscherinnen der Neuzeit wie Marie-Jeanne de Lalande oder Caroline Herschel (Bd. 30/16, 1895) erweitert. Die feministische Ahnenlinie wurde immer länger und ihr wurden auch Frauen zugerechnet, die ihren Handlungsspielraum erweitert hatten, ohne in ihrer Zeit schon grundsätzlich über Frauen- und Menschenrechte zu reflektieren - seien dies runenkundige, singende Sagafrauen und Skaldinnen oder gar Eva, über die mit etwas Augenzwinkern in einem Artikel 1898 zu lesen war: 
»Eva, welche dem Verbot zum Trotz die erste Frucht vom Baume der Erkenntnis brach, war entschieden die erste Frauenrechtlerin. Sie ist uns heutigen mit leuchtendem Beispiel voran gegangen. Sie hat uns gelehrt, zu stehlen und zu naschen, ehe es uns vergönnt ist, von aller geistigen Nahrung frei zuzulangen und uns damit zu sättigen. Und sie hat uns gelehrt, für so ehrenvollen Diebstahl zu leiden, bis man einsieht, daß es eben kein Diebstahl, sondern unser gutes Menschenrecht ist. ${ }^{52}$

Als Vertreterin der älteren, nun abtretenden Generation reflektierte die 65jährige Auguste Schmidt in dem Artikel »Die Zeit und wir!« 1898 ihre Erfahrungen in und mit der Frauenbewegung. In den stürmischen Anfängen der 1860er Jahre, im »ersten Kindesalter der Frauenbewegung«, sei sie noch überzeugt davon gewesen, dass in weniger als dreißig Jahren die Bewegung an ihr Ziel gelangt wäre. So hatte sie damals vor verdutzten und geschockten Lehrerkollegen verkündet: »In 30 Jahren sitze ich im Landtag!« In der Zwischenzeit habe sie aber »das langsame Reisen der Ideen und Rechte der Menschheit« erkannt. Damit einher ging ein justierter zeitlicher Erwartungshorizont: Nun hing für sie von der »Qualität der zukünftigen Generation studierter Frauen« ab, »wie schnell oder wie langsam wir im 20. Jahrhundert vorrücken«. Sie hoffte an ihrem Lebensabend »nicht wieder im Zeitmaß zu irren, wenn ich im Geiste im Jahre 1950 die Frauen an der ihnen längst vertrauten Wahlurne sehe und weibliche Abgeordnete im Parlament erblicke« (Bd. 33/1, 1898: 1-2). Auguste Schmidt schrieb dies zu einem Zeitpunkt, als es noch zwei Jahre dauern sollte, bis mit der badischen Universität Freiburg die erste deutsche Universität ihre Toren für Frauen öffnete. Zwei Jahrzehnte später, 1918, erhielten Frauen im Deutschen Reich schließlich das Wahlrecht. Auch diesmal also hatte sich Auguste Schmidt im Zeithorizont geirrt, denn der Zeitgeist der »Ideen und Rechte der Menschheit« war nicht immer langsam unterwegs, sondern konnte mitunter plötzlich schnelle Fahrt aufnehmen.

Über die Geschichtskonstruktionen in den Neuen Bahnen und das sich Einschreiben dieser ersten Generation von Feministinnen in die Geschichte blitzt ein Teil ihrer Identitätskonstruktion auf - als Teil der Generation der 1848er, verbunden mit den europäischen National- und Menschenrechtsbewegungen der Gegenwart und Vergangenheit. Thre nicht-hegemoniale, gleichwohl intentionale, vom Fortschritts- und Modernisierungsnarrativ beherrschte Geschichtsdeutung stellte nicht große Männer und Staaten, sondern herausragende Frauen, soziale und demokratische Bewegungen sowie humanistische Ideen ins Zentrum. Die 
Frauenbewegung konstruierte damit eine Gegengeschichte, die mit den Paradigmen der damaligen deutschen Geschichtswissenschaft an den Universitäten preußisch-kleindeutsch, auf Staaten, Monarchie, Kirche, Diplomatie, große Männer und Ideen zentriert - nur wenig gemein hatte. Die konsequent intentionale Geschichtskonstruktion der Frauenbewegung mag aus wissenschaftlichhistoristischer Sicht irritieren, sie erscheint aus politischer und feministischer Perspektive allerdings nachvollziehbar und funktional.

\section{FAZIT UND ABSCHLIESSENDER VERGLEICH}

Der Vergleich der Geschichtsdarstellungen in britischen und deutschen feministischen Zeitschriften bringt mehr Gemeinsamkeiten als Unterschiede an den Tag. So vertreten alle hier ausgewerteten Zeitschriften ein Geschichtsbild, das vom Gedanken des allgemeinen Fortschritts der Menschheit geprägt ist und eine teleologische, aufklärerisch gefärbte Sicht von Geschichte propagiert, bei der große Frauen (und Männer) der Emanzipations- und Befreiungsbewegungen sowie Künstlerinnen und Wissenschaftlerinnen der Vergangenheit als Vorbilder dienen. Auffällig ist in den britischen wie deutschen Beispielen, dass im national imprägnierten 19. Jahrhundert Frauengeschichte nicht national beschränkt war, sondern eine dezidiert transnationale Ausrichtung hatte und historische Identifikationsfiguren aus Europa und vereinzelt selbst von außerhalb Europas für die >eigene Traditionsbildung reklamiert wurden.

Gemeinsam ist den feministischen Zeitschriften des Weiteren eine intentionale Geschichtsbetrachtung. Sie konstruierten eine tendenzielle Gegengeschichte zur >allgemeinen< Historie, die Frauen und ihre Erfahrungs- und Lebensbereiche systematisch vernachlässigte, wie viele Artikel in metahistorischen Reflexionen betonten. Dem wurde in der Praxis der Zeitschriften selbst eine weibliche Historiographie in doppelter Hinsicht entgegengesetzt: Frauen sollten nicht nur in die Geschichte eingeschrieben werden, sondern diese auch selbst schreiben. Programmatisch inkorporierten die feministischen (und auch einige nichtfeministische) Frauenzeitschriften Frauen in die Geschichte und schufen so eine für Frauen identitätsstiftende >eigene< Historie. Dabei machten sie deutlich, dass die Suche nach Frauen in der Geschichte eine Perspektiverweiterung hin zu Sozial-, Kultur- und Alltagsgeschichte mit sich brachte. Im Vergleich zu den nichtfeministischen Frauenzeitschriften verfolgten die feministischen hierbei ein bewusst >seriöses< Programm, das >typisch < weibliche Bereiche wie die Geschichte der Mode, des Haushalts und der dekorativen Handarbeit weitgehend aussparte 
und stattdessen die Geschichte weiblicher Berufstätigkeit oder Bildungsleistungen in den Vordergrund rückte.

Geschichte diente den Frauenbewegungen als Ressource, um ihre politischen Forderungen zu legitimieren. Sie lieferte Nachweise über historische Leistungen von Frauen in Kunst, Wissenschaft, Erwerbsleben und Politik, mit denen sich Ansprüche auf erweiterte Handlungsspielräume in der Gegenwart untermauern ließen. Aus diesem Grund war es den Zeitschriften auch wichtig, dass ihre Leserinnen sich mit Geschichte beschäftigten.

Neben diesen vielen Gemeinsamkeiten deutet sich als Unterschied an, dass die Neuen Bahnen Geschichte stärker politisch fokussierten und instrumentalisierten als die Zeitschriften der frühen britischen Frauenbewegung. Der Grund hierfür liegt möglicherweise in den nachwirkenden und noch vorhandenen politischen Restriktionen im Kaiserreich - der Unterdrückung der demokratischoppositionellen Bewegungen nach der gescheiterten Revolution von 1848/49, der gebremsten politischen Modernisierung im Kaiserreich, dem 1878 erlassenen Sozialistengesetz sowie dem bis 1908 in vielen deutschen Staaten geltenden Vereinsgesetz von 1850, das die Partizipation von Frauen an politischen Vereinen verbot.

Es könnte aussagekräftig sein, weiterzuverfolgen, ob und wie sich die Geschichtskonstruktionen in den 1890er Jahren mit den sich ausdifferenzierenden und expandierenden Frauenbewegungen veränderten - in Deutschland mit der Ausbildung des sozialistischen, des konfessionellen sowie des radikalen Flügels, in Großbritannien mit der sich nun formierenden radikalen Suffragettenbewegung. Eine andere weiterführende Frage wäre, ob die transnationalen Gemeinsamkeiten in den Geschichtsbildern und feministischen Traditionsstiftungen die gesteigerten nationalen Antagonismen im Zeitalter des Hochimperialismus und des Ersten Weltkriegs überlebten. 


\section{LITERATUR}

Ballaster, Ros/Margaret Beetham/Elizabeth Frazer/Sandra Hebron (1991): Women's Worlds: Ideology, Femininity, and the Woman's Magazine, Basingstoke: Macmillan.

Beetham, Margaret (1996): A Magazine of Her Own? Domesticity and Desire in the Woman's Magazine, 1800-1914, London: Routledge.

Brake, Laurel/Marysa Demoor (2009): Dictionary of Nineteenth-Century Journalism in Great Britain and Ireland, London: Academic Press and The British Library.

Davis Doughan/Denise Sanchez (1987): Feminist Periodicals 1855-1984: An Annotated Critical Bibliography of British, Irish, Commonwealth and International Titles, Brighton: The Harvester Press.

Dredge, Sarah (2005): »Opportunism and Accommodation: The English Woman's Journal and the British Mid-Nineteenth-Century Women's Movement«. Women's Studies 34.2, S. 133-57.

Epple, Angelika (2003): Empfindsame Geschichtsschreibung: Eine Geschlechtergeschichte der Historiographie zwischen Aufklärung und Historismus, Köln: Böhlau.

Epple, Angelika (2004): »Questioning the Canon: Popular Historiography by Women in Britain and Germany (1750-1850)«. In: Sylvia Paletschek (Hg.), Popular Historiographies in the $19^{\text {th }}$ and $20^{\text {th }}$ Centuries, Oxford: Berghahn, S. 21-33.

Epple, Angelika/Angelika Schaser (2009): »Multiple Histories? Changing Perspectives in Modern Historiography«. In: Angelika Epple/Angelika Schaser (Hg.), Gendering Historiography: Beyond National Canons, Frankfurt: Campus, S. 7-24.

Felber, Lynette (2007) (Hg.): Clio's Daughters: British Women Making History, 1790-1899, Newark: University of Delaware Press.

Fraser, Hilary/Stephanie Green/Judith Johnston (2003): Gender and the Victorian Periodical, Cambridge: Cambridge University Press.

Gerhard, Ute (1990): Unerhört. Die Geschichte der deutschen Frauenbewegung, Hamburg: rororo.

Gerhard, Ute (2004): »The Women's Movement in Germany in an International Context«. In: Sylvia Paletschek/Bianka Pietrow-Ennker (Hg.), Women's Emancipation Movements in the 19th Century. A European Perspective, Stanford: Stanford University Press, S. 102-122.

Gerhard, Ute et al. (1979) (Hg.): »Dem Reich der Freiheit werb' ich Bïrgerinnen«. Die Frauen-Zeitung von Louise Otto, Frankfurt: Syndikat. 
Grever, Maria (1997): »The Pantheon of Feminst Culture: Women's Movements and the Organisation of Memory«. Gender \& History 9, S. 364-374.

Herstein, Sheila R. (1985): »The English Woman's Journal and the Langham Place Circle: A Feminist Forum and Its Women Editors«. In: Joel H. Wiener (Hg.), Innovators and Preachers: The Role of the Editor in Victorian England, Westport, CT: Greenwood Press, S. 61-76.

Korte, Barbara/Sylvia Paletschek (2012): »Nineteenth-Century Magazines and Historical Cultures in Britain and Germany: Exploratory Notes on a Comparative Approach«. In: Dies. (Hg.), Popular History Now and Then: International Perspectives, Bielefeld: transcript, S. 73-103.

Malečkova, Jitka (2004): »The Emancipation of Women for the Benefit of the Nation: The Czech Women's Movement«. In: Sylvia Paletschek/Bianka Pietrow-Ennker (Hg.), Women's Emancipation Movements in the 19th Century. A European Perspective, Stanford: Stanford University Press, S.167-188.

Meiners, Christoph (1799): Geschichte des weiblichen Geschlechts, 2 Bde., Hannover: Helwing.

Mitchell, Rosemary (2000): Picturing the Past: English History in Text and Image, 1830-1870, Oxford: Clarendon Press.

Mussell, Jim (2005-2007): »English Woman's Journal (1858-1864)«. In: The Nineteenth-Century Serials Edition, London: Birkbeck, University of London, King's College London, and the British Library. (http:// ncse.cch.kcl.ac.uk/headnotes/ewj.html). Zugriff am 27. Februar 2013.

Nestor, Pauline A. (1982): »A New Departure in Women's Publishing: The English Woman's Journal and The Victoria Magazine«. Victorian Periodicals Review 15.3, S. 93-106.

Nissen, Martin (2009): Populäre Geschichtsschreibung: Historiker, Verleger und die deutsche Öffentlichkeit (1848-1900), Köln: Böhlau.

Offen, Karen (2000): European Feminisms 1700-1950: A Political History, Stanford: Stanford University Press.

Paletschek, Sylvia (1998): »>Die Freiheit ist unteilbar!< Frauenemanzipation, religiöse Reform und die Revolution von 1848/49«. Ariadne: Almanach des Archivs der deutschen Frauenbewegung 33, S. 16-24.

Paletschek, Sylvia (2007): »Historiographie und Geschlecht«. In: Johanna R. Regnath/Mascha Riepl-Schmidt/Ute Scherb (Hg.), Eroberung der Geschichte: Frauen und Tradition, Hamburg: Lit Verlag, S. 105-127.

Paletschek, Sylvia (2011): »Popular Presentations of History in the Nineteenth Century: The Example of Die Gartenlaube«. In: Dies. (Hg.), Popular Historiographies in the $19^{\text {th }}$ and $20^{\text {th }}$ Centuries, Oxford: Berghahn, S. 34-53. 
Paletschek, Sylvia/Bianka Pietrow-Ennker (2004a): »Concepts and Issues«. In: Dies. (Hg.), Women's Emancipation Movements in the 19th Century: A European Perspective, Stanford: Stanford University Press, S. 3-10.

Paletschek, Sylvia/Bianka Pietrow-Ennker (2004b): »Women's Emancipation Movements in Europe in the Long Nineteenth Century: Conclusions«. In: Dies. (Hg.), Women's Emancipation Movements in the 19th Century: A European Perspective, Stanford: Stanford University Press, S. 301-336.

Paletschek, Sylvia/Sylvia Schraut (2008): »Introduction. Gender and Memory Culture in Europe - female representations in historical perspective «. In: Dies. (Hg.), The Gender of Memory: Cultures of Remembrance in Nineteenth- and Twentieth-Century Europe, Frankfurt: Campus, S. 7-26.

Pietrow-Ennker, Bianka (1999): Rußlands »neue Menschen«: Die Entwicklung der Frauenbewegung von den Anfängen bis zur Oktoberrevolution, Frankfurt: Campus.

Rendall, Jane (2004): »Recovering Lost Political Cultures: British Feminisms, 1860-1900«. In: Sylvia Paletschek/Bianka Pietrow-Ennker (Hg.), Women's Emancipation Movements in the 19th Century: A European Perspective, Stanford: Stanford University Press, S. 33-52.

Rendall, Jane (1987): »>A Moral Engine<? Feminism, Liberalism and The English Woman's Journal«. In: Dies. (Hg.), Equal or Different: Women's Politics 1800-1914, Oxford: Blackwell, S. 112-38.

Rendall, Jane (2007): »Langham Place group (act. 1857-1866)«. Oxford Dictionary of National Biography, online edition, Oxford: Oxford University Press. (http://www.oxforddnb.com/view/theme/93708). Zugriff am 27. Februar 2013.

Riepl-Schmidt, Mascha et. al. (1998): »Anna Blos, geborene Tomasczewska, Historiographin einer weiblich revolutionären Tradition - Geschichtsschreibung im Spiegel des eigenen Lebens«. In: Dies. (Hg.), Frauen und Revolution: Strategien weiblicher Emanzipation 1789 bis 1818, Tübingen: Silberburg Verlag, S. 134-156.

Schaser, Angelika (2006): Frauenbewegung in Deutschland 1848-1933, Darmstadt: wbg.

Scherr, Johannes (1860): Geschichte der Deutschen Frauen: In drei Bänden nach den Quellen, Leipzig: Wigand.

Schroeder, Janice: »On the English Woman's Journal, 1858-62«. In: Dino Franco Felluga (Hg.), BRANCH: Britain, Representation and Nineteenth-Century History: Extension of Romanticism and Victorianism on the Net.Web. (http://www.branchcollective.org/?ps_articles=janice-schroeder-on-the-eng lish-womans-journal-1858-62). Zugriff am 27. Februar 2013. 
Schwarz, Angela (2008): »Naturkunde oder Naturwissenschaft? Frauen und ihre naturwissenschaftlichen Schriften im 19. Jahrhundert«. Historische Anthropologie 16.1, S. 74-91.

Smith, Bonnie G. (1998): The Gender of History: Men, Women, and Historical Practice, Cambridge: Harvard University Press.

Smith, Bonnie G. (1984): »The Contribution of Women to Modern Historiography in Great Britain, France, and the United States, 1750-1940«. American Historical Review 89.3, S. 709-732.

Spongberg, Mary/Barbara Caine/Ann Curthoys (2005): Companion to Women's Historical Writing, Houndsmills: Palgrave.

Spongberg, Mary (2002): Writing Women's History Since the Renaissance, Basingstoke: Palgrave Macmillan.

Stoehr, Irene (1990): Emanzipation zum Staat? Der Allgemeine Deutsche Frauenverein - Deutscher Staatsbürgerinnenverband (1893-1933), Paffenweiler: Centaurus.

Stollberg-Rilinger, Barbara (1996): »Väter der Frauengeschichte? - Das Geschlecht als historiographische Kategorie im 18. und 19. Jahrhundert«. Historische Zeitschrift 262, S. 39-71.

Weckel, Ulrike (1998): Zwischen Häuslichkeit und Öffentlichkeit: Die ersten deutschen Frauenzeitschriften im späten 18. Jahrhundert und ihr Publikum, Tübingen: Niemeyer.

Wischermann, Ulla (2003): »Bewegungs(gegen)-Öffentlichkeiten: Zur Geschichte der politischen Presse von Frauen für Frauen«. Ariadne: Forum für Frauen- und Geschlechtergeschichte 44, S. 6-13.

\section{Ausgewertete Zeitschriften}

Neue Bahnen. Organ des allgemeinen deutschen Frauenvereins. Bd. 1-34, Leipzig 1866-1899.

The English Woman's Journal. In: The Gerritsen Collection, The NineteenthCentury Serials Edition (http://gerritsen.chadwyck.com).

The Englishwoman's Domestic Magazine. In: Nineteenth Century UK Periodicals: Series 1: New Readerships (http://find.galegroup.com).

The Englishwoman's Review. In: The Gerritsen Collection, The NineteenthCentury Serials Edition (http://gerritsen.chadwyck.com).

The Ladies' Treasury. In: Nineteenth Century UK Periodicals: Series 1: New Readerships (http://find.galegroup.com).

Victoria Magazine, London 1863-1880. 